\title{
STRUKTURA TERYTORIALNA DIECEZJI LUBELSKIEJ W LATACH 1805-1808
}

Diecezja lubelska powołana do życia bullą papieża Piusa VII Quemadmodum Romanorum Pontificum z dnia 23 września 1805 roku, faktycznie zaczęła funkcjonować dopiero po wydaniu dekretu wykonawczego bulli z 19 października $1807 \mathrm{roku}$, i jego realizacji przez delegata apostolskiego, metropolitę lwowskiego obrządku łacińskiego Kajetana Kickiego ${ }^{1}$. Niniejszy artykuł stanowi kontynuację poprzedniego zatytułowanego Organizacja terytorialna diecezji chetmskiej i lubelskiej do 1805 r., zamieszczonego w 94 tomie ABMK.

Przez ponad dwa lata od daty ukazania się bulli papieskiej diecezja lubelska, zachowała wewnętrzny podział na dekanaty i parafie taki, jaki ustalił się po

* Joanna Kumor-Mielnik - dr historii, asystent naukowy w Ośrodku Badań nad Geografią Historyczną Kościoła w Polsce, Wydział Nauk Humanistycznych KUL.

${ }^{1}$ Biblioteka PAU i PAN w Krakowie, Erectio sedis episcopalis Lublinensis ..., k. 1-20.; Bullarii Romani continuatio ... Tomus decimus secundus continens pontificatus PII VII., Romae 1846, s. 374-381; Catalogus universi cleri ... Anno Domini 1875, Lublin 1874, s. V-XXV.; B. Kumor, Granice metropolii i diecezji polskich (966-1939), „Archiwa, Biblioteki i Muzea Kościelne” [dalej: ABMK], 20 (1970) s. 328 [222]; B. Kumor, Ustrój i organizacja Kościoła, s.71; B. Kumor, Diecezja lubelska (180 lat istnienia), „Wiadomości Diecezjalne Lubelskie” [dalej: WDL] 59(1985) nr 5-7 s. 236-237; Archidiecezja lubelska. Historia i administracja, red. M. T. Zahajkiewicz, Lublin 2000, s. 104.; L. Zalewski, Katedra i jezuici w Lublinie, cz. 1, Lublin 1947, s. 143-144; J. Skarbek, $W$ dobie rozbiorów i braku państwowości (1772-1918), w: J. Kłoczowski, L. Müllerowa, J. Skarbek, Zarys dziejów Kościoła katolickiego w Polsce, Kraków 1986, s. 187; H. Gapski, Kalendarium Kościoła Lubelskiego, w: Skarby Archidiecezji Lubelskiej, red. P. Kawałko i in., Lublin 2005, s. 309; J. A. Wadowski, Lubelskie biskupstwo, w: Encyklopedia Kościelna podtug teologicznej encyklopedii Wetzera i Weltego z licznymi jej dopetnieniami przy wspótpracownictwie kilkunastu duchownych $i$ świeckich osób, wyd. M. Nowodworski, t. 12, Warszawa 1879, s. 346-350; Z. Chełmicki, Lubelskie bpstwo, w: Podręczna Encyklopedia Kościelna, oprac. S. Gall i in., red. Z. Chełmicki, t. 25-26, Warszawa 1911, s. 4-5.; P. Aleksandrowicz, Diecezja Siedlecka czyli Podlaska. W 150 rocznicę erekcji (1818-1968). Przyczynki i materiaty do dziejów Diecezji Siedleckiej czyli Podlaskiej, Siedlce 1971, s. 74; M. T. Zahajkiewicz, Diecezja, jej granice i organizacja terytorialna, w: Dzieje Archidiecezji Lubelskiej (1805-2005), red. M. Zahajkiewicz, Lublin 2005, s. 37-38.; K. Turowski, Diecezja lubelska, „Przewodnik Katolicki”, 58 (1968) s. 12. 
III rozbiorze Polski w diecezji chełmskiej i lubelskiej². W związku z tym do 1807 roku diecezja lubelska, funkcjonowała tylko teoretycznie, a jej struktura dekanalno-parafialna stanowiła odzwierciedlenie struktury byłej diecezji chełmskiej i lubelskiej. I tak w 1805 roku w jej granicach funkcjonowało 10 następujących dekanatów: chełmski, chodelski, krasnostawski, kurowski, lubelski, łukowski, parczewski, stężycki, urzędowski i zaklikowski ${ }^{3}$. Trzy dekanaty: chodelski, urzędowski i zaklikowski, miały zostać wyłączone w 1805 roku z diecezji lubelskiej i przekazane nowo erygowanej diecezji kieleckiej, co jednak nie zostało wykonane, bowiem biskup lubelski Wojciech Skarszewski na prośbę ordynariusza kieleckiego Wojciecha Górskiego, zatrzymał je ad interim pod swoją jurysdykcją ${ }^{4}$. Zmiany w liczbie dekanatów na obszarze diecezji lubelskiej nastapiły dopiero po wprowadzeniu w życie bulli papieskiej erygującej diecezję lubelską, czyli pod koniec 1807 roku. Wówczas to w skład nowej diecezji weszło 17 dekanatów, z czego: 7 z dawnej diecezji chełmskiej i lubelskiej (chełmski, krasnostawski, kurowski, lubelski, parczewski, łukowski, stężycki); natomiast dalsze 3 dekanaty tejże diecezji: chodelski urzędowski i zaklikowski zostały przekazane diecezji kieleckiej; 4 dekanaty z diecezji łuckiej (janowski, międzyrzecki, łosicki ${ }^{5}$ i węgrowski); z diecezji poznańskiej 3 dekanaty (garwoliński, latowicki, liwski); także 3 dekanaty z diecezji płockiej (kamieńczykowski, stanisławowski i radzymiński) ${ }^{6}$.

Już w 1808 roku dekanaty przekazane diecezji lubelskiej utworzyły nową sieć dekanalną, składającą się tak jak dotychczas z liczby 17 dekanatów, jednak o nieco zmienionej strukturze i nomenklaturze. I tak z byłej diecezji chełmskiej i lubelskiej zachowano 7 dekanatów, natomiast $\mathrm{z}$ dekanatów dawnej diecezji łuckiej, płockiej, poznańskiej utworzono 10 następujących: bialski, garwoliński,

\footnotetext{
${ }^{2}$ Kumor, Granice metropolii, ABMK 20 (1970) s. 324 [218]-325 [219].

${ }^{3}$ Catalogus Cleri Saecularis Diaecesis Helmensis et Lublinensis R. L. Episcopus Diaecesis Helmensis et Lublinensis Adalbertus Leszczyc De Skarszewski, w: Directorium Officii Divini pro Dioecesi Hetmensi et Lublinensi in Annum Christi Secundum post Bissextilem 1806.

${ }^{4}$ Biblioteka PAU i PAN w Krakowie, J. A. Wadowski, Dzieje diecezji lubelskiej, sygn. rękop. 2365, nr mikrof. 36107 (Według zapisu ks. Wadowskiego: „19 paździenika 1807 roku bp Skarszewski zawiadomił kler cyrkułu józefowskiego należący do dekanatów: chodelskiego, urzędowskiego i zaklikowskiego, że jakkolwiek na mocy bulli erekcyjnej wykonanej przez abpa. sufr. Lwowskiego odłączony jest od diecezji chełmsko-lubelskiej, a przyłączony do kieleckiej - 30 września 1807roku bp kielecki Wojciech Górski poprosił Skarszewskiego aby one pod jego jurysdykcją zostały do czasu nowej dyspozycji)"; Kumor, Granice metropolii, ABMK, 20 (1970) s. 328 [222]; Zahajkiewicz, Diecezja, jej granice, s. 39.

${ }^{5}$ Bullarii Romani continuatio summorum pontificum Clementis XIII, Clementis XIV, PII VI. PII VII. Leonis XII. PII VIII. et Gregorii XVI. ... Tomus decimus secundus continens pontificatus PII VII., Romae 1846, s. 376-377; B. Kumor zamiast dekanatu łosickiego, wymienia w swych publikacjach dekanat koszycki, który jednak nigdy nie istniał w diecezji łuckiej. Błąd przypuszczalnie wynika z niepoprawnego zapisu nazwy dekanatu.

${ }^{6}$ Archiwun Archidiecezjalne w Lublinie [dalej: AAL], sygn. Rep 60 A 259, Akta Konsystorza Generalnego Lubelskiego, Opis historyczny Diecezji Lubelskiej przez księdza Karola Boniewskiego, księga 1, s. 1-216, s. 19; Catalogus Cleri Saecularis Diaecesis Lublinensis R. L. Episcopus Diaecesis Lublinensis Adalbertus Leszczyc de Skarszewski, w: Directorium Officii Divini pro Dioecesi Lublinensi in Annum Christi Primum post Bissextilem 1809.; Kumor, Granice metropolii, ABMK, 20 (1970), s. 328 [222]; Zahajkiewicz, Diecezja, jej granice, s. 39.
} 
janowski, kamieńczykowski, latowicki, liwski, międzyrzecki, siedlecki, stanisławowski, węgrowski ${ }^{7}$. Zmiany te obrazuje dołączona do artykułu mapa, na której zaznaczono, zarówno dekanaty przyłączone do diecezji lubelskiej i wymienione $\mathrm{w}$ jej bulli erekcyjnej, ale również dekanaty powstałe po wykonaniu bulli, w roku $1807 / 8$. Zatem począwszy od 1808 roku pierwotnie w podziale dekanalnym diecezji lubelskiej możemy wyróżnić 17 dekanatów.

\section{Części składowe diecezji lubelskiej w latach 1805-1808}

Ponieważ treść bulli erygującej diecezję lubelską nakazywała odłączenie od dotychczasowej diecezji chełmskiej i lubelskiej parafii cyrkułu józefowskiego, znajdujących się w dekanatach chodelskim, urzędowskim oraz zaklikowskim i włączenie ich do diecezji kieleckiej, pojawiły się na tym tle nowe kwestie sporne związane po pierwsze z przekazaniem jurysdykcji nad tymi terenami biskupowi kieleckiemu, a po drugie ze zmianą przynależności dekanalnej parafii Turobin oraz jej filii Czernięcin. Te ostatnie parafie leżące najpierw w granicach dekanatu krasnostawskiego, a następnie urzędowskiego, zostały wyłączone $\mathrm{z}$ tego ostatniego jeszcze przed faktycznym wcieleniem go do diecezji kieleckiej, co nastąpiło w grudniu 1807 roku i przekazane dekanatowi lubelskiemu, pozostając w ten sposób w granicach diecezji lubelskiej.

Na wyłączenie z granic diecezji lubelskiej 3 dekanatów (chodelskiego, urzędowskiego i zaklikowskiego) i wcielenie ich do diecezji kieleckiej, biskup lubelski Wojciech Skarszewski wyraził zgodę dopiero 23 IX 1807 roku9.

Zatem w skład nowej diecezji lubelskiej weszły parafie znajdujące się, jak już wspomnieliśmy w 7 dekanatach pochodzących z byłej diecezji chełmskiej i lubelskiej: chełmskim, krasnostawskim, kurowskim, lubelskim, łukowskim, parczewskim i stężyckim. Dekanat chełmski organizowało 13 parafii: Chełm, Czułczyce, Dorohusk, Dubienka, Kumów, Olchowiec, Orchówek, Pawłów, Sawin, Sosnowica, Świerże, Uhrusk, Wereszczyn; dekanat krasnostawski zawierał w swoich granicach 10 parafii: Chłaniów, Gorzków, Krasnystaw, Łopiennik, Płonka Siennica Różana, Surhów, Tarnogóra, Wojsławice, Żółkiewka; także 10 parafii znajdowało się na terytorium dekanatu kurowskiego: Baranów, Bochotnica, Garbów, Gołąb, Kurów, Klementowice, Markuszów, Michów, Wąwolnica, Żyrzyn. Dekanat lubelski tworzyło 14 parafii (w tym 2 filie): (Abramowice, Bełżyce, Czerniejów, Częstoborowice, Czwartek (przedmieście Lublina), Fajsławice, Konopnica, Krężnica Jara (filia), Krzczonów, Lublin pw. św. Michała, Matczyn, Piaski, Wojciechów (filia), Zemborzyce), z kolei 16 parafii (w tym 1 filia) wchodziło w skład dekanatu

${ }^{7}$ Biblioteka PAU i PAN w Krakowie, J. A. Wadowski, Dzieje diecezji chetmskiej i lubelskiej, sygn. rękop. 2366, nr mikrof. 36127.

${ }^{8}$ Biblioteka PAU i PAN w Krakowie, J. A. Wadowski, Dzieje diecezji lubelskiej; Kumor, Organizacja terytorialna diecezji kieleckiej, „Nasza Przeszłość”, 17 (1963) s. 199 [13]-200 [14], 203 [17].

${ }^{9}$ Kumor, Organizacja terytorialna diecezji kieleckiej, s.198 [12]; Kumor, Granice metropolii, ABMK, 20 (1970) s. 328 [222]. 
łukowskiego: Adamów, Domanice, Kąkolewnica (filia), Kock, Łuków, Łysobyki, Pruszyn, Radoryż, Radzyń, Serokomla, Stanin, Trzebieszów, Tuchowicz, Ulan, Wojcieszków, Zbuczyn. Z dekanatu parczewskiego pochodziło 16 parafii oraz 2 filie (Biskupice, Bystrzyca, Czemierniki, Dys, Kamionka, Kijany, Krasienin, Lubartów, Łańcuchów, Łęczna, Mełgiew, Ostrów, Parczew, Puchaczów, Rudno, Sernki, filie w Firleju i Łuszczowie), natomiast dekanat stężycki podzielony został na 19 okręgów parafialnych, których stolicami były: Bobrowniki, Brzeziny, Drążgów, Gończyce, Górzno, Kłoczew, Korytnica, Łaskarzew, Maciejowice, Nowodwór, Okrzeja, Pawłowice, Ryki, Samogoszcz, Stężyca, Wargocin, Wilczyska, Żabianka, Żelechów. W sumie w 7 dekanatach pochodzących ze zniesionej w 1805 roku diecezji chełmskiej i lubelskiej znajdowało się 95 parafii oraz 5 filii ${ }^{10}$. Dekretem biskupa lubelskiego Wojciecha Skarszewskiego z 24 grudnia 1807 roku dołączyła do tejże grupy 1 parafia - Turobin oraz filia Czernięcin, które przez pewien czas znajdowały się w dekanacie urzędowskim włączonym $\mathrm{w}$ granice diecezji kieleckiej ${ }^{11}$. Wliczając parafię Turobin oraz filię Czernięcin do sumy 95 parafii i 5 filii otrzymujemy liczbę 102 parafii (w tym 6 filii) wchodzących w skład 7 powyższych dekanatów.

$\mathrm{Z}$ trzech pozostałych diecezji: łuckiej, poznańskiej i płockiej do diecezji lubelskiej przyłączono w sumie 106 parafii, tworzących w całości 9 dekanatów (janowski podlaski, międzyrzecki, łosicki, węgrowski, garwoliński, latowicki, liwski, kamieńczykowski, stanisławowski), a częściowo 1 (radzymiński). I tak z diecezji łuckiej przyłączono 4 dekanaty wraz z 50 parafiami. Były to: dekanat janowski podlaski, w skład którego wchodziło 10 parafii: Biała, Bordziłówka, Horbów, Huszcza, Janów Podlaski, Kodeń, Leśna, Malowa Góra, Piszczac, Pratulin. Również 10 parafii składało się na dekanat międzyrzecki (Komarówka, Łomazy, Międzyrzec, Opole, Ostrówki, Rossosz, Sławatycze, Wisznice, Włodawa, Wohyń). Wraz z dekanatem łosickim przybyło 13 parafii: Górki, Hadynów, Huszlew, Knychówek, Łosice, Mordy, Niemojki, Paprotnia, Przesmyki, Rusków, Sarnaki, Skrzeszew, Wyrozęby; natomiast 17 parafii pochodziło z dekanatu węgrowskiego (Kosów, Ceranów, Węgrów, Rozbity Kamień, Czerwonka, Wyszków, Mokobody, Kożuchówek, Suchożebry, Sokołów, Nieciecz, Miedzna, Skibniew, Sterdyń, Zembrów, Prostyń, Jabłonna) ${ }^{12}$.

${ }^{10}$ Catalogus Cleri Saecularis Diaecesis Lublinensis...1809.; Biblioteka PAU i PAN w Krakowie, J.A. Wadowski, Dzieje diecezji chetmskiej i lubelskiej.

${ }^{11}$ Kumor, Organizacja terytorialna diecezji, s. 203 [17].

12 Według badań L. Królika dekanat janowski podlaski, składał się w 1761 roku z 19 parafii (Janów, Wohyń, Międzyrzec, Ostrówki, Rossosz, Opole, Łomazy, Huszcza, Malowa Góra, Kodeń, Włodawa, Horbów, Leśna, Komarówka, Bordziłówka, Sławatycze, Piszczac, Wisznice, Pratulin). Około 1782 roku z dekanatu janowskiego wydzielono dekanat międzyrzecki. Skład parafialny dekanatu łosickiego w 1755 roku był taki sam jak w zapisie bullowym diecezji lubelskiej - w 1805 roku; z kolei liczba parafii dekanatu węgrowskiego z 1791 roku różniła się nieznacznie od liczby parafii odnotowanej w roku 1805. Różnica ta dotyczyła 2 parafii: Jarnice oraz Stara Wieś, które pojawiły się na obszarze dekanatu węgrowskiego w 1791 roku, natomiast brak ich w roku 1805; L. Królik, Organizacja dekanalna diecezji tuckiej i brzeskiej w XVII i XVIII wieku, Lublin 1981; L. Królik, Organizacja diecezji tuckiej i brzeskiej od XVI do XVIII wieku, Lublin 1983. 
Diecezja poznańska utraciła na rzecz diecezji lubelskiej 3 dekanaty w granicach których funkcjonowało 37 parafii. Dekanat garwoliński posiadał na swym obszarze 13 parafii (Długa, Garwolin, Glinianka, Goźlin, Karczew, Kołubiel (Kołbiel), Osieck, Ostrówek, Siennica, Tarnówek, Warszawice, Wiązowna, Wilga), z kolei dekanaty zarówno latowicki, jak i liwski składały się z 12 parafii. Do dekanatu latowickiego należały: Borowie (Borów), Jeruzal, Kiczki, Kuflew, Latowicz, Miastków, Seroczyn, Stoczek, Wodynie, Żeliszew, Zwola, Parysów, natomiast wraz z dekanatem liwskim zostały wcielone następujące parafie: Cegłów, Czerwonka, Grębków, Jakubów, Kałuszyn, Kopcie, Liw, Mińsk, Niwiska, Oleksin, Wierzbno, Wiśniew.

Z diecezji płockiej do lubelskiej zostało w 1807 roku formalnie przyłączonych 19 parafii, funkcjonujących w granicach 3 dekanatów: kamieńczykowskiego (tworzyło go 9 parafii: Jadów, Kamieńczyk, Korytnica, Niegów, Podstoliska, Sadowne, Stoczek, Sulejów, Kamionna); stanisławowskiego, w skład którego wchodziło 8 parafii: (Cygów, Dobre, Klembów, Kobyłka, Pustelnik, Pniewnik, Okuniew oraz Stanisławów) oraz radzymińskiego z którego wydzielono 2 parafie: Radzymin oraz Dąbrówkę ${ }^{13}$. Poszczególne części składowe nowo erygowanej diecezji lubelskiej w liczbach bezwzględnych i wartościach procentowych przedstawia poniższa tabela.

Tabela 1. Części składowe diecezji lubelskiej, na podstawie jej bulli erekcyjnej z 1805 r.

\begin{tabular}{|c|c|c|c|c|}
\hline Diecezja & Dekanat & Liczba parafii (bez filii) & Udzial procentowy & Liczba filii \\
\hline 1 & 2 & 3 & 4 & 5 \\
\hline \multirow{7}{*}{ Chełmska i lubelska } & Chełmski & 13 & - & - \\
\hline & Krasnostawski & 10 & - & - \\
\hline & Kurowski & 10 & - & - \\
\hline & Lubelski & 13 & - & 3 \\
\hline & Lukowski & 15 & - & 1 \\
\hline & Parczewski & 16 & - & 2 \\
\hline & Steżycki & 19 & - & - \\
\hline Ogólem & 7 dekanatów & 96 & $47,5 \%$ & 6 \\
\hline \multirow{4}{*}{ Łucka } & Janowski Podlaski & 10 & - & - \\
\hline & Łosicki & 13 & - & - \\
\hline & Międzyrzecki & 10 & - & - \\
\hline & Węgrowski & 17 & - & - \\
\hline Ogólem & 4 dekanaty & 50 & $24,8 \%$ & - \\
\hline
\end{tabular}

${ }^{13}$ Bullarii Romani continuatio summorum pontificum Clementis XIII, Clementis XIV, PII VI. PII VII. Leonis XII. PII VIII. et Gregorii XVI. ... Tomus decimus secundus continens pontificatus PII VII., Romae 1846, s. 376-377; Catalogus Universi Cleri ... Anno Domini 1875, (s. X-XII: Documentum II).; B. Kumor, Granice diecezji płockiej, w: Studia Płockie. Jubileuszowa Ksiega Pamiatkowa 900-lecia Diecezji, red. J. Kłoczowski, cz. 1, t. 3, Płock 1975, s. 51-52. 


\begin{tabular}{|c|c|c|c|c|}
\hline \multirow{3}{*}{ Płocka } & Kamieńczykowski & 9 & - & - \\
\hline & Radzymiński & 2 & - & - \\
\hline & Stanisławowski & 8 & - & - \\
\hline Ogółem & 3 dekanaty & 19 & $9,4 \%$ & - \\
\hline \multirow[t]{3}{*}{ Poznańska } & Garwoliński & 13 & - & - \\
\hline & Latowicki & 12 & - & - \\
\hline & Liwski & 12 & - & - \\
\hline Ogółem & 3 dekanaty & 37 & $18,3 \%$ & - \\
\hline Razem & 17 & 202 & $100 \%$ & $6 *$ \\
\hline
\end{tabular}

* W tekście bulli erygującej diecezję lubelską, zawierającym nazwy parafii z części diecezji łuckiej, płockiej i poznańskiej pominięte zostały filie, zaś niektóre filie zostały zapisane jako parafie. Zawarte w tabeli statystyki, sporządzone są zgodnie z treścią bulii, zawartej w: Catalogus Universi Cleri Saecularis et Regularis Dioecesis Lublinensis Anno Domini 1875, (s. X-XII: Documentum II).; Bullarii Romani continuatio summorum pontificum Clementis XIII, Clementis XIV, PII VI. PII VII. Leonis XII. PII VIII. et Gregorii XVI. ... Tomus decimus secundus continens pontificatus PII VII., Romae 1846, s. 376-377.; Biblioteka PAU i PAN w Krakowie, Erectio sedis episcopalis Lublinensis. Bulla Piusa VII z 22 IX 1805 r. Odpis ks. Jana Fijatka, sygn. rękop. 4805.

Wymienione powyżej parafie należące przed rokiem 1805/7 do diecezji łuckiej, płockiej i poznańskiej po 1807 roku na skutek reorganizacji sieci dekanalnej, zostały ulokowane w 10 dekanatach (bialskim, garwolińskim, janowskim, kamieńczykowskim, latowickim, liwskim, międzyrzeckim, siedleckim, stanisławowskim, węgrowskim $)^{14}$. Terytorium pierwszego z nich pokryte zostało siecią 9 parafii (w tym 1 filii): Biała, Bordziłówka, Górki, Hadynów (filia), Huszlew, Leśna, Łosice, Rusków, Sarnaki. Z kolei w granicach dekanatu garwolińskiego znalazło się 13 parafii: Długa Kościelna, Garwolin, Glinianka, Goźlin, Karczew, Kołubiel (Kołbiel), Osieck, Ostrówek, Siennica, Tarnówek (Tarnów), Warszawice, Wiązowna, Wilga.

8 parafii (w tym 1 filia) weszło w skład dekanatu janowskiego podlaskiego (Horbów, Huszcza - filia, Janów Podlaski, Kodeń, Malowa Góra, Piszczac, Pratulin, Terespol). Strukturę dekanatu kamieńczykowskiego stanowiło 10 parafii (Dąbrówka, Jadów, Kamieńczyk, Kamionna, Korytnica, Niegów, Postoliska, Sadowne, Stoczek Węgrowski, Sulejów) ${ }^{15}$; dekanatu latowickiego 13 parafii (Borowie, Jeruzal, Kiczki, Kuflew, Latowicz, Miastków, Parysów, Seroczyn, Skórzec, Stoczek Łukowski, Wodynie, Zwola i Żeliszew); zaś dekanatu liwskiego 12 parafii (Cegłów, Czerwonka, Grębków, Jakubów, Kałuszyn, Kopcie, Liw, Mińsk Mazowiecki, Niwiski, Oleksin, Wierzbno i Wiśniew) ${ }^{16}$. Granice 10 parafii (Komarówka, Łomazy, Międzyrzec, Opole, Ostrówki, Rossosz, Sławatycze, Wiszni-

${ }^{14}$ Biblioteka PAU i PAN w Krakowie, J.A. Wadowski, Dzieje diecezji chetmskiej i lubelskiej.

${ }^{15}$ Catalogus Cleri Saecularis Diaecesis Lublinensis...1809 r.; Wadowski, Dzieje diecezji chetmskiej i lubelskiej.

${ }^{16}$ www.diecezja.waw.pl; S. Litak, Kościót taciński w Rzeczypospolitej około 1772 roku, Lublin 1996, s. 301.; M. Wrzeszcz, Latowicz, w: Encyklopedia Katolicka, red. A. Szostek i in., t.10, s. 1282-1283. 
ce, Włodawa, Wohyń $)^{17}$ zakreślały obszar dekanatu międzyrzeckiego, z kolei na obszarze dekanatu siedleckiego znajdowało się 12 parafii oraz 1 filia (Jabłonna, Knychówek, Kożuchówek, Mordy, Nieciecz, Niemojki, Paprotnia, Przesmyki, Siedlce, Skrzeszew, Suchożebry, Wierów (filia), Wyrozęby) ${ }^{18}$. W dekanacie stanisławowskim swoich siedzib miało 9 parafii (Cygów, Dobre, Klembów, Kobyłka, Okuniew, Pniewnik, Pustelnik, Radzymin, Stanisławów), zaś 14 parafii (w tym 1 filia) organizowało obszar dekanatu węgrowskiego (Ceranów, Czerwonka, Kosów, Mokobody, Miedzna, Prostyń, Rozbity Kamień, Skibniew, Sokołów Podlaski, Stara Wieś - filia, Sterdyń, Węgrów, Wyszków, Zembrów). W 10 dekanatach utworzonych z parafii wchodzących przed erygowaniem biskupstwa lubelskiego w skład diecezji łuckiej, płockiej i poznańskiej odnotowaliśmy 111 parafii (w tym 8 filii).

Organizacja sieci parafialno-dekanalnej, zaprowadzona w 1807 roku (weszła w życie z początkiem 1808 roku) na terytorium będącym niegdyś częścią diecezji łuckiej, płockiej i poznańskiej, różniła się od dotychczasowej tylko na paru odcinkach. Po pierwsze powstały na tym obszarze 2 nowe dekanaty: bialski, wydzielony częściowo z dekanatu janowskiego, zaś częściowo z łosickiego, przy czym skrawek tego ostatniego wraz z częścią dekanatu węgrowskiego utworzyły drugi nowy dekanat - siedlecki. Dekanat łosicki rozdzielony pomiędzy 2 nowopowstałe dekanaty: bialski i siedlecki, przestał istnieć. Ponadto poza zmianą granic dekanatu janowskiego na korzyść bialskiego i węgrowskiego na korzyść siedleckiego, przesunięciu uległy także granice dekanatu kamieńczykowskiego oraz stanisławowskiego, do których wcielono po 1 parafii przyłączonej z dekanatu radymińskiego, którego nazwa zniknęła z obszaru diecezji lubelskiej. W składzie pierwszego z nich znalazła się parafia Dąbrówka, zaś do drugiego przyłączono parafię Radzymin. Niezmienione pozostały granice 4 dekanatów: garwolińskiego, liwskiego, latowickiego oraz międzyrzeckiego.

Konkludując, suma wszystkich parafii oraz filii znajdujących się w 1807 roku na obszarze nowo erygowanej diecezji osiągnęła wartość 213 (199 parafii oraz 14 filii).

\section{Projekty regulacji granicy diecezjalnej oraz granic dekanalnych przyszlej diecezji lubelskiej po 1799 roku}

Zanim na mocy bulli z 1805 roku erygowano diecezję lubelską, w 1799 roku część jej terytorium, funkcjonująca pod nazwą diecezji chełmskiej i lubelskiej, którą zarządzał bp Wojciech Skarszewski, została na polecenie władz austriackich poddana regulacji sieci dekanalnej, mającej na celu dostosowanie podziału na dekanaty do nowej administracji państwowej (cyrkułów) zaprowadzonej w Galicji Zachodniej. W diecezji chełmskiej i lubelskiej projekt reorganizacji sieci dekanalnej przewidywał zniesienie dekanatu kazimierskiego i utworzenie dwóch nowych w Kurowie i Zaklikowie. W galicyjskiej części diecezji łuckiej, która w 1805 roku

${ }^{17}$ Aleksandrowicz, dz. cyt., s. 67.

${ }^{18}$ Biblioteka PAU i PAN w Krakowie, J. A. Wadowski, Dzieje diecezji chetmskiej i lubelskiej.; Catalogus Cleri Saecularis Diaecesis Lublinensis 1809 r. 
weszła w skład diecezji lubelskiej, zniesieniu miał ulec dekanat łosicki, w miejsce którego planowano powołać dekanat siedlecki, jednocześnie pozostawiając dekanaty w Janowie Podlaskim, Białej, Międzyrzecu i Węgrowie. Dekanaty z diecezji poznańskiej włączone w 1805 roku w granice diecezji lubelskiej, a więc garwoliński, latowicki i liwski, miały pozostać niezmienione, natomiast dekanaty z części diecezji płockiej: radzymiński, stanisławowski i kamieńczykowski, miały ulec reorganizacji polegającej na zniesieniu dekanatu radzymińskiego i pozostawieniu dwóch ostatnich. Zmiany te miały wejść w życie pod koniec 1799 roku, jednakże zostały one zaprowadzone dopiero po wykonaniu bulli erekcyjnej diecezji lubelskiej w 1807 roku, bowiem bulla ta w przypadku części diecezji łuckiej, płockiej i poznańskiej, wymienia ich dawny podział dekanalny ${ }^{19}$. Z kolei obecność dekanatu zaklikowskiego i kurowskiego na obszarze diecezji chełmskiej i lubelskiej obserwujemy dopiero od $1801 \mathrm{r}^{20}$.

W związku z ukształtowaniem się w 1807 roku nowej organizacji terytorialnej diecezji lubelskiej, pojawiły się na tym tle także kwestie wątpliwe. Po pierwsze złożony i kontrowersyjny problem przynależności dekanalnej Siedlec oraz utworzenia dekanatu siedleckiego ujawniła konfrontacja informacji pochodzących z opracowań z samym zapisem bullowym oraz materiałem źródłowym. Według B. Kumora dekanat siedlecki powstał już pod koniec 1799 roku w galicyjskiej części diecezji łuckiej na skutek zniesienia istniejącego tam dekanatu łosickiego. Fakt ten miał nastąpić po tym jak biskup (wówczas jeszcze chełmski i lubelski) Wojciech Sakrszewski dnia 20 czerwca 1799 roku przekazał parafie Siedlce położoną dotychczas w dekanacie łukowskim (w granicach diecezji chełmskiej i lubelskiej), pod zarząd administratora galicyjskiej części diecezji łuckiej. Bulla erygująca diecezję lubelską, nie wymienia wśród dekanatów i parafii części diecezji łuckiej przyłączonej do diecezji lubelskiej ani dekanatu siedleckiego, jak również samej parafii Siedlce. Prawdopodobnie w momencie sporządzania projektu bulli parafia Siedlec funkcjonowała jeszcze $w$ granicach diecezji chełmskiej i lubelskiej, w dekanacie łukowskim, co może sugerować, że informacje zbierane do projektu bulli pochodziły sprzed roku 1799, a więc sprzed daty włączenia parafii Siedlce do diecezji łuckiej, bądź też w bulli nie uwzględniono zmiany przynależności diecezjalnej oraz dekanalnej Siedlec, jaka nastąpiła w roku 1799.

${ }^{19}$ Kumor, Ustrój i organizacja Kościoła polskiego w okresie niewoli narodowej 1772-1918, Kraków 1980, s. 527-529.; Bullarii Romani continuatio summorum pontificum Clementis XIII, Clementis XIV, PII VI. PII VII. Leonis XII. PII VIII. et Gregorii XVI. ... Tomus decimus secundus continens pontificatus PII VII., Romae 1846, s. 376-377.; Catalogus universi cleri saecularis et regularis Dioecesis Lublinensis Anno Domini 1875, Lublin 1874, s. V-XXV (Documentum II - ingrosowany dokument wykonania bulli przez delegata apostolskiego, abpa lwowskiego Kajetana Kickiego).; Biblioteka PAU i PAN w Krakowie, Erectio sedis episcopalis Lublinensis. Bulla Piusa VII z 22 IX 1805r. Odpis ks. Jana Fijałka, sygn. rękop. 4805, k. 1-20.

${ }^{20}$ Directorium Officii Divini pro Dioecesi Hetmensi et Lublinensi in Annum Christi Tertium post Communem 1803. Conscriptum Sub Authoritate Illustrissimii Excellentissimi et Reverendissimi Domini Adalberti Skarszewski. 
Według luźnego wykazu Ecclesia Parochiales Diaecesis Luceoriensis in Galicia Occidentali ${ }^{21}$ na jaki napotkaliśmy w Archiwum Archidiecezjalnym w Lublinie parafia Siedlce po przekazaniu jej pod jurysdykcję biskupa galicyjskiej części diecezji łuckiej znalazła się w granicach dekanatu węgrowskiego, jednakże nie mamy pewnego potwierdzenia tego faktu w innego rodzaju źródłach, chociażby $\mathrm{w}$ formie dekretu. Ponadto bulla erygująca diecezję lubelską nie wymienia parafii Siedlce wśród parafii przyłączonych z diecezji łuckiej do lubelskiej, gdyż jak wiemy obok istniejącego już od 1790 roku terytorium diecezji chełmskiej i lubelskiej, zgodnie z bullą nowa diecezja lubelska miała się składać z części diecezji płockiej poznańskiej oraz łuckiej. Brak parafii siedleckiej wśród wyszczególnionych w tekście bulli z 1805 roku, innych parafii diecezji łuckiej, pomimo iż znalazła się ona na jej obszarze już w 1799 roku, jak również, pominięcie w tekście tegoż dokumentu papieskiego nowo powstałych diecezji: warszawskiej powstałej głównie z części diecezji poznańskiej w 1798 oraz wigierskiej utworzonej z części diecezji łuckiej, wileńskiej i żmudzkiej w 1799 roku może wskazywać na fakt, iż tekst bulli erygującej diecezję lubelską został spisany przed rokiem 1798. Rozbieżność pomiędzy zapisem bullowym, a stanem faktycznym, jaki zaistniał po roku 1799 skłoniła nas do przedstawienia w tekście i jednocześnie zobrazowania na mapie części składowych diecezji lubelskiej zgodnych z treścią jej bulli erekcyjnej, co zostało podkreślone także w tytule zestawienia tabelarycznego. W związku z czym, parafia Siedlce, po 1807 roku stolica dekanatu siedleckiego utworzonego z części dekanatu węgrowskiego i łosickiego znalazła się zgodnie z kanonem bulli w granicach dekanatu łukowskiego.

Przedstawione zmiany terytorialne nadawały kształt tworzącym się w tym czasie strukturom terytorialnym przyszłej diecezji lubelskiej, do których właściwej organizacji przystąpiono jak wyżej wspomniano dopiero po wykonaniu postanowień bulli erekcyjnej w październiku 1807 roku.

Powyższy zarys zmian w kościelnej geografii historycznej (archi)diecezji lubelskiej, jaki dokonał się na przestrzeni zaledwie kilku lat, jest tylko wprowadzeniem w głębszą problematykę związaną z reorganizacją sieci dekanatów oraz parafii, bowiem w związku z dokonującymi się przez dwa wieki zmianami granic diecezji, a od 1992 archidiecezji lubelskiej, wyłoniło się w tym okresie wiele kwestii spornych dotyczących parafii położonych w pobliżu linii demarkacyjnych tejże (archi)diecezji.

${ }^{21}$ AAL, Akta Konsystorza Generalnego Lubelskiego, Urządzenie diecezji Chetmsko-Lubelskiej, później Lubelskiej 1761-1838, sygn. Rep 60 I 131, k. 231. 


\title{
THE TERRITORIAL STRUCTURE OF THE DIOCESE OF LUBLIN IN THE YEARS 1805-1808.
}

\begin{abstract}
Summary
The above text continues the issues contained in the article which appeared in the previous (94) volume of this academic journal. It concerns the process of marking the boundaries of the diocese of Chelm and Lublin, which originated the diocese of Lublin in 1805. The leitmotif of this article is historical and geographical analysis of the territorial formation of the diocese of Lublin from the moment of issuing the foundation bull to the year when all the directives from the bull were implemented, and the structure of deaneries and parishes for the new diocese was completely established. The article focuses on the boundary delimitation of the diocese of Lublin and shows the problems connected with the organization of its territorial structures, and above all problems arising from the modification in the existing structure of deaneries and parishes. Cartographic presentation of the parts of diocese of Lublin and its territorial organization enables to make comparative analysis of the contents of the foundation bull for the diocese of Lublin and its later deanery and parish structure, which was legitimized after 1807.

The boundary instability of the diocese of Chełm and Lublin, which was the result of the changes in the delimitation due to the partition of Poland beginning at the end of the 18th century, is the reason why this article is accompanied by a few maps, the aim of which is to illustrate each and every modification to the boundaries of the diocese of Chełm and Lublin and to show its parts along with the marked capitals of the deaneries.
\end{abstract}


Diecezja chełmska i archidiakonat lubelski w latach 1772-1782

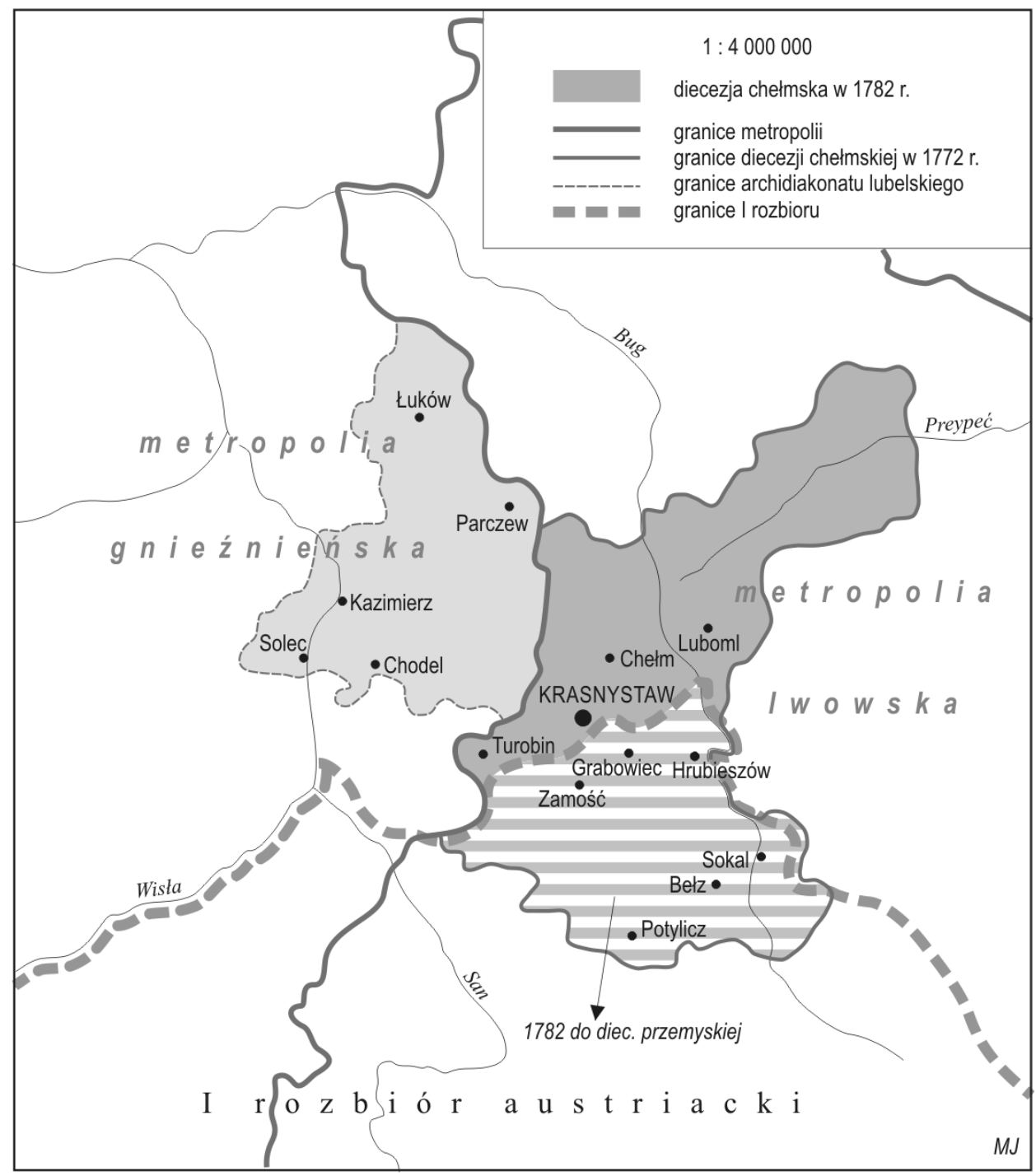

oprac. kartograficzne Maria Juran, WH KUL 


\section{Diecezja chełmska i lubelska w latach 1790-1795}

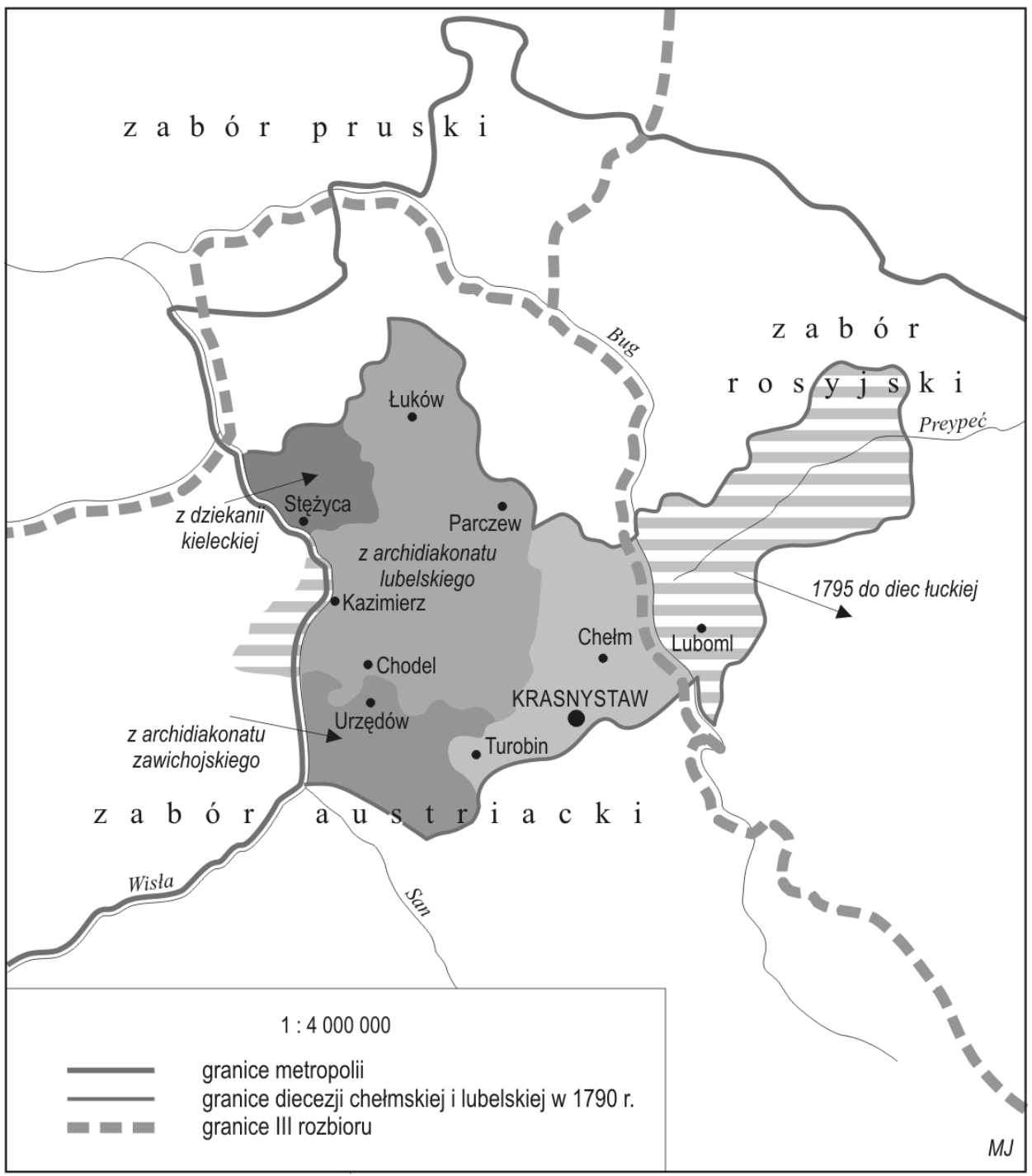

oprac. kartograficzne Maria Juran, WH KUL 
Diecezja chełmska i lubelska w1802 roku

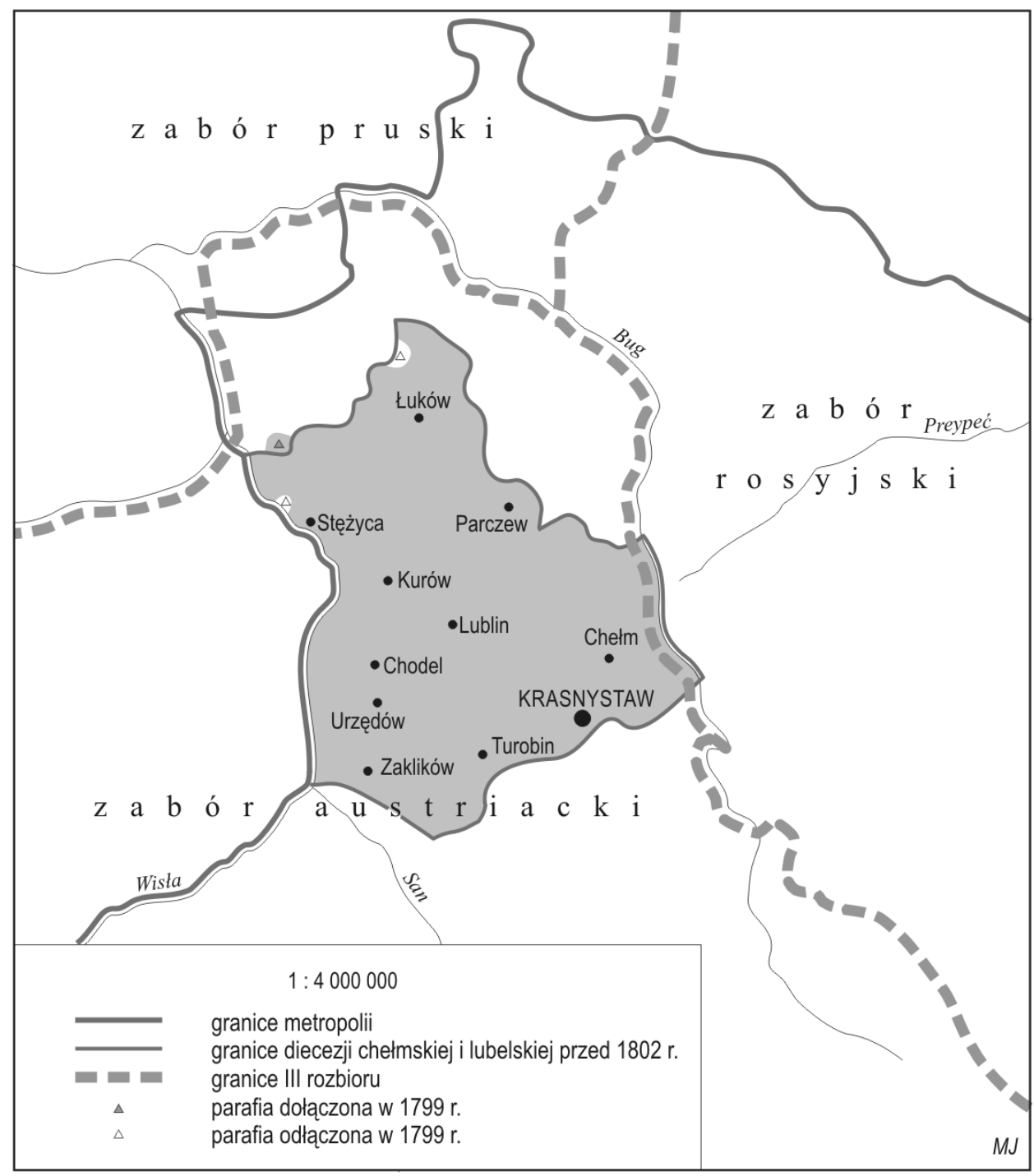

oprac. kartograficzne Maria Juran, WH KUL 
DEKANATY PRZYLACZONE NA PODSTAWIE BULLI ERYGUJACEJ DIECEZJĘ LUBELSKA ORAZ DEKANATY ORGANIZUJACE JEJ OBSZAR PO WYKONANIU BULLI

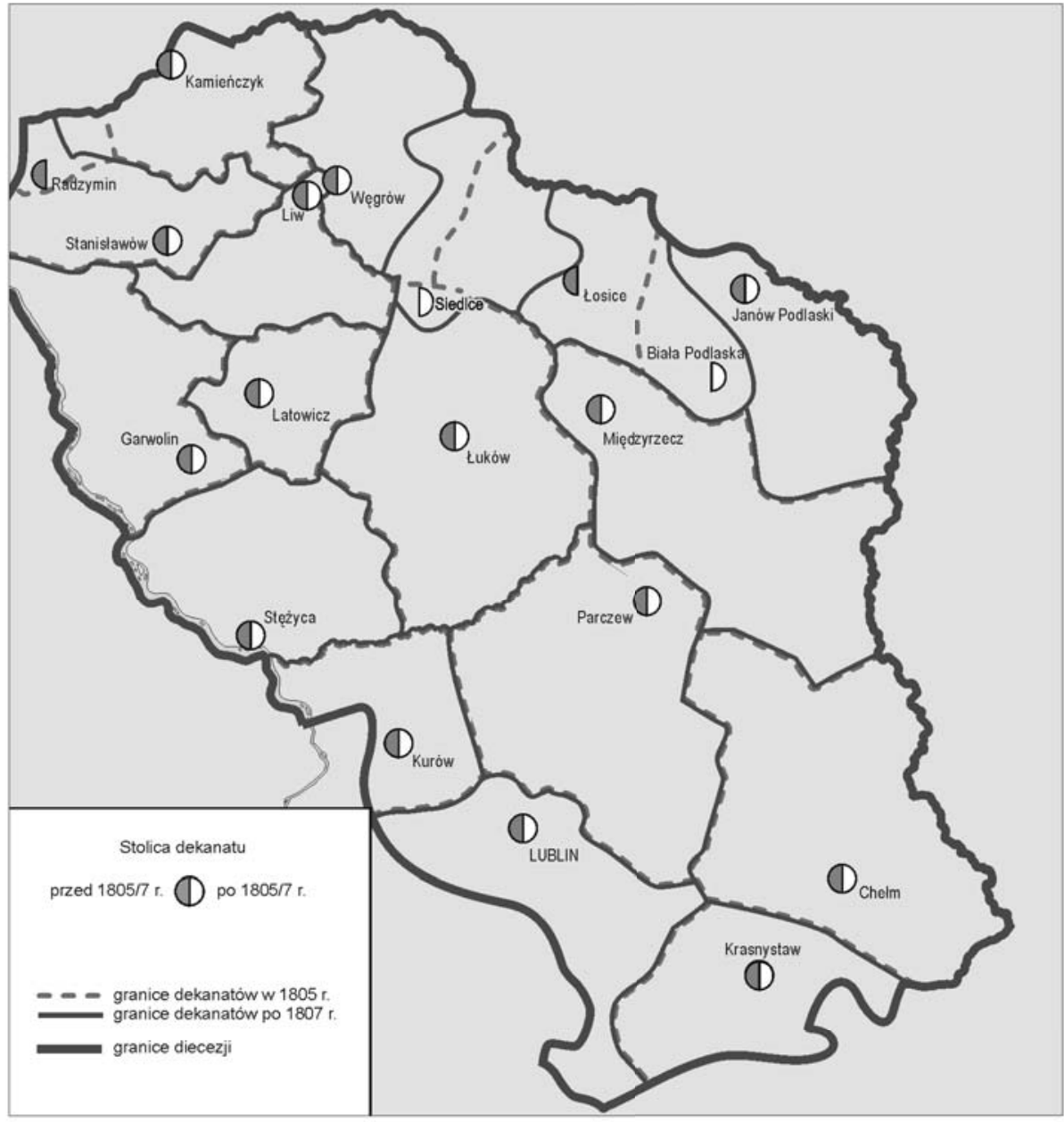

